\title{
Analysis of the Factors that Influence the Incidence of Low Birth Weight (BBLR) in Bojonegoro District
}

\author{
Wahyu Rusmitawati ${ }^{1}$, Byba \\ Melda $^{2}$, Ratna Wardani ${ }^{3}$ \\ ${ }^{1}$ Health Department of \\ Bojonegoro Regency \\ ${ }^{2}$ Institute of Health Science \\ Strada Indonesia, Kediri \\ ${ }^{3}$ Institute of Health Science \\ Strada Indonesia, Kediri \\ Email: \\ itawahyu17@gmail.com
}

Received: March $5^{\text {th }} 2021$

Accepted : May $6^{\text {th }} 2021$

Published : May $20^{\text {th }} 2021$

\begin{abstract}
Low Birth Weight is health problems that need to be addressed seriously because is an indicator to determine health level of the nation. South East Asia has 20-35 \% of infants born with Low Birth Weight and $70-80 \%$ neonates were death because of premature infants and Low Birth Weight. In Bojonegoro district since 3 years ago, has fluctuated cases of Low Birth Weight. The purpose of this research to know the impact of nutritional status of mothers, gestational age, disorder/comorbidities of disorder, exposure to cigarette smoke, parity and regularity examination pregnancy relating Low Birth Weight in Bojonegoro district. The methodology of this research is analytic correlational by approach cross sectional. The population research is all women rise in November 2019- January 2020 in public health center area Balen, Ngasem, Kedungadem Bojonegoro district. The technique of this research used proportional random sampling by using 133 samples. Analysis techniques data using regression double logistics. The result showed that a variable that influence the incidence Low Birth Weight is the nutritional status $(\mathrm{p}=0,000)$, disorder/ comorbidities of comorbidities $(\mathrm{p}=0,013)$ and parity $(\mathrm{p}=0,008)$. While variables that not affected to Low Birth Weight is gestational age, exposure to cigarette smoke and regularity examination pregnancy. Six variables with negelkerke has value $\mathrm{R}=$ 0,658 capable of being explained Low Birth Weight factors influencing the cases.
\end{abstract}

Keywords: Level of health, nutrition status, disorder, comorbidities, parity, LBW

Copyright @ 2021 IIK STRADA Indonesia All right reserved.

This is an open-acces article distributed under the terms of the Creative Commons Attribution-ShareAlike 4.0 International License.

\section{INTRODUCTION}

Low Birth Weight is defined as a baby with birth weight less than 2,500 grams without looking at the pregnancy age (WHO, 2011). Through the profile of the East Java Health Office in the last three years, the percentage of Low Birth Weight compared with the number of births weighed has fluctuated, $3.6 \%$ in 2016 and increased to $3.8 \%$ in 2017, in 2018 the percentage fell to $3.7 \%$ or as 
many as 21,544 babies (Dinas Kesehatan Jawa Timur, 2019). Bojonegoro District in 2016, the percentage of Low Birth Weight was 4.9\%, then decreased to 4.7\% in 2017 and increased in 2018 to $4.72 \%$ or as many as 811 babies from 16,785 newborns which were weighed (Dinas Kesehatan Bojonegoro, 2019). The highest rate of cases was found in 3 (three) Public Health Service, Balen Public Health Service with 48 cases, Ngasem Public Health Service with 37 cases and Kedungadem Public Health Service with 36 cases. Risk factors that influence the cases of Low Birth Weight according to the Committee of Institute of Medicine (1985), are the socio-demographic characteristics of the mother (age less than 20 years and age more than 34 years, black race, poor socioeconomic status, illegitimate marriage, low level of education), medical risks before and during pregnancy (parity, birth spacing, weight and height, chronic disease (DM, hypertension), infectious diseases, anemia, once given birth to Low Birth Weight, spontaneous abortion, multiple pregnancy, pregnancy complications and placental issues), personal and environmental risk factors (smoking, poor nutrition, alcohol and drug abuse, occupational risk, physical and psychosocial stress, and high altitude), and antenatal care factors that are not adequate (Rabe, 2010).Researchers want to analyze the influence and risk factors that are most dominant, which can affect the cases of Low Birth Weight in Bojonegoro District at Ngasem and Kedungadem Public Health Service.

\section{MATERIALS AND METHODS}

This study used a case control design, the population of this study were mothers that gave birth in November 2019 - January 2020 at Balen, Ngasem, and Kedungadem Public Health Service in Bojonegoro District. The number of samples in this study were 133 people. The independent variables in this study were nutritional status, pregnancy age, comorbidities (hyperemesis gravidarum, anemia, gemelli, pre-eclampsia and eclampsia), exposure to cigarette smoke, parity and ANC. The dependent variable in this study was the cases of Low Birth Weight. The sampling used is proportional random sampling. The instrument used for the independent variable was a questionnaire for mothers and the dependent variable was the observation from the MCH handbook. The analysis in this study were univariate analysis and multivariate analysis. Multivariate analysis using logistic regression analysis. Before starting the research, the researcher will explain the research, if respondent agree to the research, the researcher will ask the respondent to fill out the consent form. Respondents only use their initials name, the data collected is only reported to respondents and study interests. This research has passed the ethical approval with number:1763/KEPK/II/2020. 


\section{RESULTS}

The general characteristics obtained from 133 samples at three Public Health Services, namely Balen, Ngasem, and Kedungadem, obtained data as follows.:

Table 1.1 Respondent Characteristics based on age, level of education, and job in Balen, Ngasem, and Kedungadem Public Health Services, Bojonegoro District in November 2019-January 2020

\begin{tabular}{llc}
\hline \multicolumn{1}{c}{$\begin{array}{c}\text { Respondent } \\
\text { Characteristics }\end{array}$} & n & \% \\
\hline Age & 105 & 78,95 \\
20-30 years & 28 & 21,05 \\
>30 years & & \\
Education & 21 & 15,79 \\
Junior High School & 94 & 70,68 \\
High School & 18 & 13,53 \\
Bachelor & & \\
Job & 68 & 51,13 \\
Farmer/housewife & 65 & 48,87 \\
Employee/ Entrepreneur & & \\
\hline
\end{tabular}

From this research, it can be concluded that of the 133 respondents there are 105 respondents (78.95\%) aged 20-30 years. 94 respondents (70.68\%) had high school education level. Meanwhile, the majority of mothers work as farmers / housewife as many as 68 respondents $(51.13 \%)$.

The description of newborn weight based on maternal factors as seen from the $\mathrm{MCH}$ handbook includes nutritional status, pregnancy age, comorbidities/diseases (hyperemesis gravidarum, anemia, gemelli, pre-eclampsia and eclampsia), exposure to cigarette smoke, parity, and regularity of antenatal care. Can be seen from the following table. 
Table 1.2 Characteristics of respondents based on the description of the $\mathrm{MCH}$ handbook in the working areas of the Balen, Ngasem, and Kedungadem Public Health Services, Bojonegoro District in November 2019-January 2020

\begin{tabular}{|c|c|c|}
\hline Mother Characteristics & $\mathbf{n}$ & $\%$ \\
\hline \multicolumn{3}{|l|}{ Nutritional Status (circumference) } \\
\hline Chronic Lack of Energy(circumference $<23,5$ ) & 72 & 54,1 \\
\hline $\begin{array}{l}\text { Non Chronic Lack of Energy (circumference } \geq \\
23,5 \text { ) }\end{array}$ & 61 & 45,9 \\
\hline \multicolumn{3}{|l|}{ Pregnancy Age } \\
\hline Aterm ( $\geq 37$ weeks $)$ & 46 & 34,59 \\
\hline Not yet Aterm $(<37$ weeks $)$ & 87 & 65,41 \\
\hline \multicolumn{3}{|l|}{ Comorbidities / diseases } \\
\hline Have disorder (minimal one pregnancy disorder) & 83 & 62,40 \\
\hline No disorder & 50 & 37,60 \\
\hline \multicolumn{3}{|l|}{ Exposure to cigarette smoke } \\
\hline $\begin{array}{l}\text { Any exposure from active or passive smoker (any } \\
\text { smoker in family member) }\end{array}$ & 81 & 60,90 \\
\hline No exposure & 52 & 39,10 \\
\hline \multicolumn{3}{|l|}{ Parity } \\
\hline Primipara (first birthing) & 56 & 42,10 \\
\hline Multipara (more than one time birthing) & 46 & 34,59 \\
\hline Grande multipara (more than four time birthing) & 31 & 23,31 \\
\hline \multicolumn{3}{|l|}{ Regularity of antenatal care } \\
\hline $\begin{array}{l}\text { Regular } \\
\text { - } \quad \text { once in first trimester } \\
\text { - } \quad \text { once in second trimester } \\
\text { - } \quad \text { twice in third trimester }\end{array}$ & 44 & 33,08 \\
\hline Irregular & 89 & 66,92 \\
\hline
\end{tabular}

Table 1.3. Distribution of Low Birth Weight cases in the working areas of the Balen, Ngasem, and Kedungadem Public Health Services, Bojonegoro District in November 2019-January 2020

\begin{tabular}{ccrc}
\hline No & c Status & $\mathrm{N}$ & $\%$ \\
\hline & Low Birth Weight $(<2.500$ grams $)$ & 74 & 55.64 \\
& Not Low Birth Weight $(\geq 2500$ grams $)$ & 59 & 44.36 \\
\hline
\end{tabular}

Specific data that can be presented from this research contained 74 cases (55.64\%) of Low Birth Weight in the working areas of Balen, Ngasem, and Kedungadem Public Health Services. Another finding obtained from this research is that cases of women with Chronic Lack of Energy are quite high, 72 cases $(54.1 \%$ ), with pregnancy age that has not yet reached aterm as many as 87 cases $(65.41 \%)$. Most of the pregnant women who gave birth at that 3 Public Health Services were mothers with a first pregnancy of 56 people $(42.10 \%)$, pregnant women in the working areas of that 3 Public Health Services also mostly had comorbidities as many as 83 cases (62.40\%). Mothers were also exposed to cigarette smoke during their pregnancy, which was large number, namely 81 people $(60.90 \%)$, most of the mothers did not have routine antenatal care as many as 89 people $(66.92 \%)$ 
this was because the mother felt healthy and had no complaints. in pregnancy, the mother rarely performs examinations in the early trimester.

Multivariate Analysis

Hypothesis testing to find the effect of nutritional status, pregnancy age, comorbidity / diseases (hyperemesis gravidarum, anemia, gemelli, pre-eclampsia and eclampsia), exposure to cigarette smoke, parity, and regularity of antenatal care on Low Birth Weight cases in Bojonegoro district. The results of the analysis using logistic regression are illustrated in the following table:

\begin{tabular}{lcc} 
Table 1.4. Logistic Regression Test Result \\
\hline \multicolumn{1}{c}{ Variabel } & $\begin{array}{c}\text { Sig } \\
\text { part }\end{array}$ & Exp B \\
\hline $\begin{array}{l}\text { Nutritional Status } \\
\text { Pregnancy Age }\end{array}$ & 0,000 & $44,324^{*}$ \\
$\begin{array}{l}\text { Comorbidities / } \\
\text { diseases }\end{array}$ & 0,073 & $3,084^{* *}$ \\
$\begin{array}{l}\text { Exposure to } \\
\text { cigarette smoke }\end{array}$ & 0,013 & $0,187^{*}$ \\
$\begin{array}{l}\text { Parity } \\
\text { Regularity of } \\
\text { antenatal care }\end{array}$ & 0,059 & $0,296^{* *}$ \\
\end{tabular}

Notes:

$$
\begin{aligned}
& * \quad: \text { sig at } \alpha 5 \% \\
& * * \quad \text { sig at } \alpha 10 \%
\end{aligned}
$$

There is an effect from nutritional status of mothers to the Low Birth Weight case, where mothers with nutritional status of Chronic Lack of Energy will have a 44,324 times likelihood of experiencing Low Birth Weight case than mothers with nutritional status without Chronic Lack of Energy. This effect is statistically significant $(\mathrm{OR}=44.324 ; \mathrm{P}=0.000)$. The next factor was pregnancy age, in this research there is no effect from pregnancy age and Low Birth Weight case as statistically proven $(\mathrm{p}=0.073)$. The factor of comorbidity / disease to the Low Birth Weight case was proven to significantly influence the Low Birth Weight case $(\mathrm{OR}=0.987 \mathrm{p}=0.013)$. So that the possibility of mothers with comorbidity / diseases has an Low Birth Weight case by 0.987 times greater than mothers who do not experience comorbidity / diseases. Cigarette smoke was found have no effect on the Low Birth Weight case in this study with a p-value of 0.059 . There was an effect of parity on Low Birth Weight case (OR $=0.344 ; \mathrm{p}=0.008$ ), where mothers with multiparous grandparents gave birth more frequently to low weight babies. Mothers with high parity (grandemultipara) had an incidence of Low Birth Weight 0.344 times greater than mothers with low parity (primiparous). The checking regularity factor in this study was found to have no significant effect on the Low Birth Weight case in Bojonegoro District $(\mathrm{OR}=0.389 ; \mathrm{p}=0.144)$.

\section{DISCUSSION}

\section{The Effect of Nutritional Status Factor (Chronic Lack of Energy) on Low Birth Weight Cases}

In this study the parameter used circumference. Acording Tang, et al (2016) the anthropometric measurement of circumference is an indicator of subcutaneous fat and muscle so that it can be used to determine protein reserves in the body. 
Based on the results of research at 3 Public Health Services in Bojonegoro District, it was found that most mothers who gave birth experienced Chronic Lack of Energy (circumference $<23.5 \mathrm{~cm}$ ) as many as 72 respondents (54.1\%), Result of cross tabulation between nutritional status with Low Birth Weight cases shows that 72 respondents with Chronic Lack of Energy and experiencing Low Birth Weight cases as many as $64(48.12 \%)$.

The results of the logistic regression analysis shows that the nutritional status variable obtained p-value on $0,000(p=0,000<\alpha=0.05)$, which means Ho is rejects, the conclusion, there is relation between nutritional status and Low Birth Weight cases. Based on the Odd Ratio interpretation, it shows that mothers with nutritional status of Chronic Lack of Energy will have 44,324 times the possibility of experiencing Low Birth Weight case than mothers with nutritional status without Chronic Lack of Energy. The results of this research are in line with research conducted by Syofianti (2008) in Sawahlunto District which states that there is a significant relationship between the risk of Chronic Lack of Energy and Low Birth Weight case, where mothers with circumference $<23.5 \mathrm{~cm}$ have the opportunity to give birth to Low Birth Weight 4.56 times compared with mothers with LILA $\geq 23.5 \mathrm{~cm}$. It is also in line with the expression Purwaningsih (2007) that women of fertile age who are Chronic Lack of Energy will be at risk of giving birth to Low Birth Weight.

Meanwhile, a study conducted by Saraswati (2010) in Sukabumi District and Bunadi (2006) where the results of the study stated that mothers who had a circumference $<23.5 \mathrm{~cm}$ had a 2.5 times greater risk of giving birth to Low Birth Weight compared to mothers with circumference $\geq 23.5 \mathrm{~cm}$.

\section{The Effect of Pregnancy Age Factor on Low Birth Weight Cases}

Based on the results of the research, 133 respondents in 3 Public Health Services in Bojonegoro District showed that most of the respondents with not aterm pregnancies ( $<37$ weeks) were 87 respondents $(65.41 \%)$. Meanwhile, the cross tabulation results between pregnancy age and Low Birth Weight cases showed that mothers who experienced Low Birth Weight were mothers whose pregnancy age $(<37$ weeks) or has not reached aterm, namely $54(40.60 \%)$.

Logistic regression analysis of pregnancy age variable obtained $\mathrm{p}$-value 0.073 which means $(\mathrm{p}=$ $0.073>\alpha=0.05$ ), which means that Ho is accepted, the conclusion, there is no relation between pregnancy age and Low Birth Weight cases. Based on Odd Ratio interpretation, it shows that mothers with aterm pregnancy have a tendency of 3.084 times to experience Low Birth Weight.

The results of this research are in line with Sunarseh (2018) indicated by p value $=0.190$, which means that there is no relationship between pregnancy age and the case of low birth weight babies at the Saptosari Outpatient Public Health Services at Gunungkidul. Leonardo (2011) research entitled" "Differences in fetal outcomes at preterm delivery at 34-36 weeks of gestation with or without premature rupture of membranes" showed no relation between pregnancy age and Low Birth Weight case stating that women with preterm aged 34-36 weeks or less than 37 weeks can deliver Low Birth Weight.

This research was not in line with Sulistyorini (2010) which showed that there was a relation between pregnancy age and Low Birth Weight $(p=0.009)$ where $p<0.05$. Merzalia $(2012)$ in East Belitung District, Bangka Belitung Islands Province in 2012 showed that there was a relation between pregnancy age and the Low Birth Weight case with a $\mathrm{p}$ value of 0,000 and an OR value of 137, 360. And the results of Aulia (2019) research explained that there was a significant relation between pregnancy age and Low Birth Weight cases at Siti Khaijah Islamic Hospital at Palembang in 2018 was seen from the $\mathrm{p}$ value $=0.001$ and OR: 5.778 .

According to researchers, gestational age is not related to the incidence of low birth weight due to term pregnancy caused by several factors such as preeclampsia, chronic energy deficiency (Chronic Lack of Energy), history of shortness of breath, placental insufficiency, moderate anemia, placenta previa, hydramnios and premature rupture of membranes. Because of these factors, the fetus is born in a LBW condition even though the condition is term. 


\section{The Effect of Comorbidity / Disease Factor on Low Birth Weight Cases}

Based on the results of the research, 133 respondents in 3 Public Health Services in the Bojonegoro District showed that most pregnant women that have comorbidity / disease (at least 1 pregnancy disorder) as many as 83 respondents (62.40\%), while the results of cross tabulation between comorbidity / disease and Low Birth Weight cases shows that pregnant women who have comorbidity / disease (at least 1 pregnancy disorder) experience a Low Birth Weight of 54 (40.60\%).

The results of the logistic regression analysis showed that the variable comorbidity / disease obtained a p-value of $0.013(\mathrm{p}=0.013<\alpha=0.05)$, which means Ho is rejects, the conclusion, there is relation between the mother with comorbidity / disease with Low Birth Weight case. Based on Odd Ratio interpretation, it shows that mothers with comorbidity / disease have a Low Birth Weight case rate of 0.987 times greater than mothers without comorbidity / disease.

The risk of giving birth to Low Birth Weight occurs in pregnant women if the hemoglobin level is less than $10 \mathrm{~g} / \mathrm{dl}$ (Bunadi, 2006). According to research conducted by Bunadi (2006), it was found that there was a significant relation between hemoglobin levels $<11 \mathrm{~g} \%$ and Low Birth Weight with a $\mathrm{p}$ value of 0.001 and OR indicated that pregnant women who had hemoglobin levels $<11 \mathrm{~g} \%$ would be at risk of giving birth in Low Birth Weight 2,243 times from mothers who have hemoglobin levels $\geq 11$ $\mathrm{g} \%$. The results of Mahayana (2015) research at M. Jamil Hospital at Padang District showed that Low Birth Weight case was born on mothers who had risk factors for anemia (56.8\%), pregnant women who suffered from anemia experienced preterm labor 2.5 times greater than those who did not anemia.

Sulistyorini (2010) research at Banjarnegara Public Health Services shows that the Gemelli variable has a significant value $(p=0.029)$ and the anemia variable has a significant value $(p=0.018)$, which means that both variables have an effect on Low Birth Weight cases. In line with Roudbari (2007) research conducted in Iran, it was found that the percentage of multiple births was $65.4 \%$ and mothers with medical illnesses were $23 \%$. This study is in accordance with research conducted by Mitao et al. (2016) in Northern Tanzania, which states that pre-eclampsia has a significant relation with Low Birth Weight Mothers who experience preeclampsia have a risk of giving birth to Low Birth Weight 3.9 times compared to mothers without preeclampsia.

\section{The Effect of Exposure to Cigarette Smoke Factor on Low Birth Weight Cases}

Based on the results of the research, 133 respondents in 3 Public Health Services in Bojonegoro District, from 133 respondents, some of the mothers were exposed to cigarette smoke, either active or passive smokers, as many as 81 respondents (60.9\%) exposed to cigarette smoke both active and passive smokers experienced Low Birth Weight cases of 51 respondents $(38.35 \%)$.

The results of the logistic regression analysis showed that the variable exposure to cigarette smoke obtained a p-value of $0.059(\mathrm{p}=0.059>\alpha=0.05)$, which means that Ho is accepted, the conclusion, there is no relationship between exposure to cigarette smoke and Low Birth Weight cases. Based on the Odd Ratio interpretation, it shows that mothers who are not exposed to cigarette smoke exposure to either active or passive smokers have a 0.296 times greater tendency to Low Birth Weight.

The results of this research are in line with Fajriana (2018) which shows the results of the analysis that there is no significant relation $(\mathrm{p}=0.253)$ between exposure to cigarette smoke and Low Birth Weight case in Semampir District, Surabaya. Wahabi (2013) stated that there was no significant difference between babies born to passive smoking and non-passive smoking pregnant women

\section{The Effect of Parity Factor on Low Birth Weight Cases}

Based on the results of research at 3 Public Health Services in Bojonegoro District, it was found that from 133 respondents most of them were primipara mothers or as many as 56 respondents (42.10\%). Result of cross tabulation between parity with Low Birth Weight cases shows that 38 respondents $(28.57 \%)$ who experienced Low Birth Weight were multipara mothers.

The results of the logistic regression analysis shows that the parity variable obtained p-value of $0.008(\mathrm{p}=0.008<\alpha=0.05)$, which means Ho is rejects, the conclusion, there is relation between parity 
and Low Birth Weight cases. Based on the Odd Ratio interpretation, it shows that mothers with high parity (grande multipara) had a risk of Low Birth Weight 0.344 times greater than mothers with low parity (primipara). The results of this research are in line with Handayani (2008) that there is a relation between parity and Low Birth Weight case, indicated by a $\mathrm{p}$ value $<0.05$ and $\mathrm{OR}=3.6$. The majority of mothers giving birth were multiparous as many as $68.2 \%$ of respondents and had a risk of 3.6 to give birth to Low Birth Weight. The same result was shown by Kumar (2010), that preterm births were found at parity $>3$ with a risk of 0.92 times compared to parity $\leq 3$. According to the research by Ohlsson (2008), perinatal mortality rate was increased at parity four and incidence was low at parity two and three.

This study is also in line with research conducted by Salmawati (2011) in Lalan District, Musi Banyu Asin Regency, it was found that there was a significant relation between parity and the Low Birth Weight cases, where multiparous mothers had a risk of 3.162 times greater than primipara. Trihardiani (2011) research showed the same results, there is significant relation between parity and birth weight $(\mathrm{p}=0.043)$.

\section{The Effect of Regularity of Antenatal Care Factor on Low Birth Weight Cases}

Based on the results of research from 133 respondents in 3 Puskesmas in the Bojonegoro district, it was found that most of the respondents did not regularly check their pregnancies as many as 89 respondents $(66.91 \%)$, while the results of the cross tabulation between regular antenatal care (ANC) and the incidence of Low Birth Weight showed that 56 respondents $(42.11 \%)$ who experienced irregular Low Birth Weight in their pregnancy checks.

The results of the logistic regression analysis showed that the antenatal care (ANC) regularity variable obtained a $p$-value of $0.144(p=0.144>\alpha=0.05)$, which means that Ho is accepted, the conclusion is that there is no influence between regularity of antenatal care and the incidence of Low Birth Weight. and based on the Odd Ratio interpretation, it shows that mothers who regularly perform antenatal care have a tendency to experience Low Birth Weight incidence of 0.389 times than mothers who do not regularly perform antenatal care.

The results of this study are in line with the study of Trihardiani (2011) which shows that there is no relation between the frequency of antenatal care and the incidence of Low Birth Weight in the working areas of Singkawang Utara and Singkawang Timur Puskesmas, Singkawang City. Research by Sholiha (2015) on the Risk Analysis for Low Birth Weight in Primigravida in the city of Probolinggo obtained $p=0.35$, which means that there is no relation between regularity of antenatal care and the incidence of Low Birth Weight.

\section{Analysis of the most dominant factors on the incidence of Low Birth Weight in Bojonegoro District}

Based on the result of the three independent variables that affect the dependent variable, the one that has the strongest influence on the incidence of Low Birth Weight is nutritional status. It can be seen in the results of the $p$-value of $0,000(p=0,000<\alpha=0.05)$, which means that it has a very strong influence and at $\exp \mathrm{B}$ is 44,324. The most dominant factor associated with the incidence of Low Birth Weight in Bojonegoro district is nutritional status with $\mathrm{OR}=44.324$, meaning that mothers with Chronic Lack of Energy nutritional status are at risk of giving birth to $n$ babies by 44.324 times greater than mothers with non Chronic Lack of Energy nutritional status. Has an R square value of 0.702 , which means that the ability of the independent variables in this study to explain the relation with the dependent variable is $70.2 \%$. 


\section{CONCLUSION}

The conclusion of this research as follows:

1. Nutritional status variable (Chronic Lack of Energy), disorders/comorbidities and parity have influence on the incidence of Low Birth Weight Infants in Bojonegoro District.

2. Age of pregnancy variables, exposure of cigarette smoke and regularity of antenatal care (ANC) did not have impact to the cases of Low Birth Weight in Bojonegoro District.

3. Nutritional status variable (Chronic Lack of Energy) is most influential factor to the cases of Low Birth Weight in Bojonegoro District.

The suggestion of this research as follows:

1. For Researcher : We hoped that it can provide additional literature to conduct further research and develop the ability to apply the result of research systematically.

2. For Department : In the educational program, this research can be useful as input or reference for further research and can give contribution of thought and reference for science in the field of health in general and midwifery in particular.

3. For Society : We hoped that it can be used as reference for the community to pay more attention on health during pregnancy, and to gain insight to factors that caused the case of Low Birth Weight.

4. For Institution : We hoped that it can contribute in the efforts to reduce the Infant Mortality Rate due to Low Birth Weight in Bojonegoro District.

\section{ACKNOWLEDGMENT AND CONFLICT OF INTEREST}

The researchers gratefully acknowledge to head of the Health Departement Bojonegoro district, head of Public Health Balen, Ngasem and Kedungadem in Bojonegoro district who has granted research permission. Thanks to all respondents and midwives in Public Health area of the Balen, Ngasem and Kedungadem in Bojonegoro district who helped collecting data.

In this study, researchers used the assistance of midwives in Public Health area of the Balen, Ngasem and Kedungadem in Bojonegoro district to filling out the questionnaire, so it is possible that the results will be biased because perceptions between individuals are different. The parameters for determining the nutritional status of pregnant women, namely circumference $\leq 23.5 \mathrm{~cm}$, while the other parameters are not used in this case.

\section{REFERENCES}

Aulia, M., et al (2019) 'Hubungan Anemia, Usia Kehamilan, Dan Preeklampsia dengan Kejadian BBLR di RSI Siti Khadijah Palembang Tahun 2018', Stikes Muhammadiyah Palembang, 7(2).

Bunadi (2006) Analisis Faktor-Faktor Yang Berhubungan Dengan Kejadian BBLR Di Kota Cirebon Tahun 2004. Universitas Indonesia.

Dinas Kesehatan Bojonegoro (2019) Profil Kesehatan Bojonegoro 2018. Kabupaten Bojonegoro.

Dinas Kesehatan Jawa Timur (2019) Profil Kesehatan Jawa Timur 2018. Surabaya. Available at: https://dinkes.jatimprov.go.id/userfile/dokumen/BUKU PROFIL KESEHATAN JATIM 2018.

Fajriana, et al. (2018) 'Faktor Risiko Yang Berhubungan Dengan Kejadian Bayi Berat Lahir Rendah di Kecamatan Semampir Surabaya (Risk Factors Associated with Low Birth Weight at Semampir District, Surabaya)', MGI, 13, pp. 71-80.

Handayani, et al (2008) Paritas dengan Kejadian Berat Badan Lahir Rendah di Rumah Sakit Umum Pusat DR Soeradji Tirtonegoro Klaten Tahun 2008. STIKES Muhammadiyah Klaten.

Kumar, et al (2010) 'Maternal Indication And Obstetric Outcome In The North Indian Population: A 
Hospital-Based Study', Postgrad Med, 56(3), pp. 192-5.

Leonardo (2011) Perbedaan Luaran Janin Pada Persalinan Preterm Usia Kehamilan 34-36 Minggu Dengan Atau Tanpa Ketuban Pecah Dini, Jurnal Kesehatan. Universitas Diponegoro.

Mahayana, et al (2015) 'Faktor Risiko yang Berpengaruh terhadap Kejadian Berat Badan Lahir Rendah di RSUP Dr. M. Djamil Padang Tahun 2015', Jurnal Kesehatan Andalas, 4, p. 3.

Merzalia, N. (2012) Determinan Kejadian Berat Badan Lahir Rendah (BBLR) di Kabupate Beliting Timur Provinsi Kepulauan Bangka Belitung Tahun 2011. Universitas Indonesia.

Mitao et al. (2016) 'Risk Factors and Adverse Perinatal Outcome Associated of Low Birth Weight in Northern Tanzania: A Registry Based Retrospective Cohort Study', Asian Pacific Journal of Reproduction, (maret 2016).

Ohlsson A., S. P. (2008) Determinants and Prevention of Low Birth Weight : a Synopsis of The Evidence. Alberta institute of Health Economics.

Purwaningsih, E. (2007) Dampak Gangguan Gizi Sejak Awal Kehamilan Dalam Terjadinya Penyakit Di Usia Dewasa (Suatu Kajian Ilmu Gizi Dan Epidemiologi). Universitas Diponegoro.

Rabe, T. (2010) Buku Saku Ilmu Kebidanan I. 1st edn. Jakarta: Hiprokates.

Roudbari, et al (2007) 'Prevalence and Risk Factor of Low Birth Weight Infants in Zahedan, Islamic Republic of Iran', Eastern Mediterranean Health Journal, 13(838-4).

Salmawati (2011) Hubungan Antenatalcare dengan Kejadian BBLR Tahun 2009-2010 di Kecamatan Lalan Kabupaten Musi Banyuasin Sumatra Selatan. Universitas Indonesia.

Saraswati, E. (2010) 'Resiko Ibu Hamil Kurang Energi Kronik (KEK) dan Anemia untuk Melahirkan Bayi dengan Berat Badan Lahir Rendah (BBLR)', Jurnal PGM, 21.

Sholiha, H. dan S. S. (2015) Analisis Resiko Kejadian Berat Bayi Lahir Rendah (BBLR) pada Primigravida. Universitas Airlangga.

Sulistyorini, et al (2010) 'Analisis Faktor-Faktor yang Mempengaruhi Kejadian BBLR di Puskemas Perkotaan Kabupaten Banjarnegara'. Available at: https://jurnal.unimus.ac.id/index.php/psn12012010/article/viewFile/1197/1250.

Sunarseh (2018) Faktor-Faktor yang Berhubungan dengan Kejadian BBLR di UPT Puskesmas Rawat Jalan Saptosari Gunungkidul. Fakultas Ilmu Kesehatan Universitas 'Aisyiyah, Yogyakarta.

Syofianti, H. (2008) Pengaruh Risiko Kurang Energi Kronis Pada Ibu Hamil Terhadap Berat Badan Bayi Lahir Rendah (Analisis Kohort Ibu di Kabupaten Sawahlunto-Sijujung Tahun 2007). Universitas Indonesia.

Trihardiani, I. (2011) Faktor Risiko Kejadian Berat Badan Lahir Rendah Di Wilayah Kerja Puskesmas Singkawang Timur Dan Utara Kota Singkawang. Universitas Diponegoro.

Wahabi, H. A. et al. (2013) 'Effects Secondhand Smoke on The Birth Weight of Term Infants and the Demographic Profile of Saudi Exposed Women', BMC Public Health, 13(341), pp. 1-6. Available at: https/bmcpublichealth.biomedcentral.com/articles/10.1186/1471-2458-13-341.

WHO (2011) Optimal Feeding Of Low Birth weight Infants in Low-And Middle Income Countries. Geneva, Switzerland. 